\title{
General Narrative
}

\section{Author(s): Sven Hedin}

Source: The Geographical Journal, Vol. 33, No. 4 (Apr., 1909), pp. 353-359+361-363+365$367+369-371+373-377+379-383+385-387+389-392$

Published by: geographicalj Stable URL: http://www.jstor.org/stable/1777211

Accessed: 27-06-2016 03:22 UTC

Your use of the JSTOR archive indicates your acceptance of the Terms \& Conditions of Use, available at

http://about.jstor.org/terms

JSTOR is a not-for-profit service that helps scholars, researchers, and students discover, use, and build upon a wide range of content in a trusted digital archive. We use information technology and tools to increase productivity and facilitate new forms of scholarship. For more information about JSTOR, please contact support@jstor.org.

The Royal Geographical Society (with the Institute of British Geographers), Wiley are collaborating with JSTOR to digitize, preserve and extend access to The Geographical Journal 


\section{The}

\section{Geographical Journal.}

No. 4.

APRIL, 1909.

VoL. XXXIII.

\section{JOURNEYS IN TIBET, 1906-1908.*}

\section{GENERAL NARRATIVE.}

\section{By Dr. SVEN HEDIN.}

Every one acquainted with the map of Tibet will think this map (p. 516) an extraordinary one, as it is not like even the very latest maps published in Europe. We are accustomed to regard Tibet as an enormous plateauland situated between the two highest mountain systems on the earth's surface, Kwen-lun and Himalaya, and from the comparatively level surface of this plateau we are accustomed to think mountains rise as groups or islands, or as small short ranges. Only the Kwon-lun ranges, Arka-tagh, the eastern part of the Koko-shilis, and Tang-la, and some of the ranges situated between the upper courses of the Indo-Chinese rivers were really drawn on the maps as uninterrupted ranges; and the same was of course the case with those parts of West Tibet which have been surveyed by the Survey of India, and where the Karakorum is the most magnificent of all. But for the rest of Tibet, the interior of this the most enormous protuberance $c$ : upheaval of the Earth's crust, our maps have hitherto been uncertain, and in vain we have tried to find any kind of orographical order or plausible systematic arrangement of the mountains.

However, if one uses and compares critically all the material that has been brought home by the few explorers who have crossed the interior of this mysterious country, one will easily find that even if the different routes are far apart, they are anyhow sufficient for drawing the most important conclusions. On my journey, 1899-1902, when I crossed Eastern Tibet on three different meridional lines, I had an p. 516.

* Read at the Royal Geographical Society (Queen's Hall), February 8, 1909. Map,

No. IV.-APRIL, 1909.] 
excellent opportunity to examine the situation and east-west direction of a whole series of ranges from the country of Lop in the north to $31 \frac{1}{2}^{\circ} \mathrm{N}$. in the south, and I indicated them on a general map. Farthest north we have the Ustun-tagh, the boundary range of the Kwen-lun sloping down to the basin of Eastern 'Turkestan, and south of it several other ranges belonging to the same system, and spreading out like the fingers of a hand to the east-for instance, Akatotagh, Yilve-chimen, Piaslik-tagh, Chimen-tagh, etc. Then follows the highest range of the Kwen-lun system-Arka-tagh. South of Arka-tagh is an enormous latitudinal valley, and south of it is the range of Kokoshili, or "the green hills," so called by the Tajinur-mongols of Tsaidam. Then my three routes cross a range which is the western continuation of the Mongolian Dungbure, and south of it I crossed, again three times, the range which, further east, is called Buka-mangna, or "the wild yak's head," by the Mongolian pilgrims going to Lhasa. Only once 1 crossed in a very high double pass the gigantic range Tang-la, which was made famous some sixty-three years ago by Abbé Huc's journey; and finally, south of Tang-la, I crossed a whole series of smaller ranges stretching east and west, the southernmost of them situated on the southern shore of Selling-tso and Naktsang-tso, or Tso-ngombo.

Now, I have only mentioned the most important ranges. They are separated from each other by very broad latitudinal valleys; but in those valleys, which it takes often three days to cross, there are innumerable small ranges, which it is-almost impossible to follow, as they are generally interrupted, and in some cases simply to be regarded as ramifications from the high ranges.

Some one may ask: Well, you know the orographical arrangement and the parallelism of the ranges in this part of Tibet, but how do you know that the same laws prevail to the east and west through the whole country? Then I will reply that on my journey of 1896 I went for two months straight east, with Arka-tagh on my left and Koko-shili on my right, without crossing a single pass until I turned north-east, crossing Arka-tagh in the Mongolian pass of Yike-tsohandaban. Further, we have Wellby's and Malcolm's journey of the same year, 1896, through the whole of Northern Tibet from Ladak to the upper part of the northeru branch of Yang-tse-kiang, Napchitaï-ulan-muren, the source of which they discovered. On the whole of this great journey through Northern 'Tibet they had the Koko-shili range on their left and Dungbure on their right, and had not to cross a single pass worth mentioning until they turned north-east and went over the Koko-shili. Those two routes are a very important control to the fact that the mountain ranges of Changtang stretch uninterruptedly west to east.

Between my routes of 1900 we have the route of Bonvalot and Prince Henry of Orléans of 1889, and they crossed the same ranges as $\mathrm{I}$, but by other passes. To the east the information given by the 
Lazarist fathers, Huc and Gabet, 1845, by General Prjevalsky on his several famous journeys from 1870 to 1885 , and by Rockhill's fine journey of 1892 , is quite sufficient to make it possible to follow the ranges far to the east, the Koko-shili being called Bayankhara-ula, south of the source of Hwang-ho, the Dungbure stretching between Yang-tse-kiang and the northern Mekong branch, the Bukamangna between the two Mekong branches, the Tang-la being a watershed between Mekong and Salwen.

As to the country to the west the material existing seems also to be sufficient for reliable conclusions. Here we have first Littledale on his audacious journey, 1894-5, and west of him Dutreuil de Rhins and Grenard, 1893, their map being one of the best ever made in Tibet. Then follows a great gap, the greatest unexplored patch still left in Tibet, and then my route of 1906 , on which I crossed the western continuation of the two ranges $\mathrm{I}$ knew before, and which had been crossed, as stated, by Littledale and de Rhins. One step further west we have Bower's journey of 1891, and then the several routes of Deasy, 1898, and Rawling, 1903, both equally important and both giving us the most accurate and excellent maps of Western Tibet, as I have been able to prove more than once. Between their many routes up and down is my last journey of 1908 , when $I$, as far as to Lemchung-tso, had very little to add to their thorough exploration, and when I crossed for the sixth time this enormous range, being the western continuation of Tang-la, and nothing else than the eastern continuation of Karakorum. As to the westernmost part of the Karakorum-Tang-la range, it has of course been crossed by I do not know how many explorers-Adolf Schlagintweit, who was, I believe, the first European to reach Eastern Turkestan from India in 1857, and murdered in Kashgar; Johnson, the first British explorer to Khotan, 1865; Hayward, murdered on his way; Shaw; Dalgleish, murdered on the Karakorum pass; Younghusband several times, more especially on his famous journey over the Mus-tagh pass, and many many others. I crossed the Karakorum pass in 1902, and then, in 1906, a pass situated a little to the east of Chang-lung-yogma, which was taken by the Forsyth Embassy to Yakub Beg of Kashgar in 1873, information which I got from old Guffaru, one of my servants, who had followed Forsyth to Kashgar and seen the great Yakub Beg in all his pomp and state. Lanek-la is also a Karakorum pass, and has been crossed by several explorers, all British.

When going from India to Eastern 'Turkestan one crosses north of the Karakorum range two very considerable ranges-the Suget range in Suget-davan, a continuation of Koko-shili, and the Sandshu range in Sandshu-davan, the continuation of Arka-tagh. The Dungbure and Buka-mangna die away to the west before they have reached so far. Far West, in countries under British rule, it is easy to study the 
parallelism of the mountain ranges by help of the admirable maps of the Survey of India. A country with this strictly parallel arrangement of the ranges is called in German a "Faltenland," and a mountain system with the same orographical architecture a "Faltengebirge," and Tibet is the greatest Faltenland of the earth, although Persia is also a beautiful example of the same structure.

It is, of course, impossible to give a sufficient description of the physical geography of such a great country as Tibet in one or two hours, Tibet being four times as big as France. I will only mention that between the several ranges stretching through the whole of Chang-tang, there are latitudinal valleys, and that every one of them is divided into a great number of self-contained basins, i.e. without outlet to the ocean, or even to Eastern 'Turkestan or Tsaidam. In the bottom of almost every such depression is a salt lake, where the rock salt, carried down by small brooks, has accumulated for thousands of years. As a rule, the ground of the latitudinal valleys is very level; as I said, Wellby had almost no passes to cross on his long journey through Tibet, but going from north to south I had a lot of passes to wander over.

Many different agencies are working constantly to level out the country. The capillary frost forces the hardest rocks to burst and fall into pieces; the finer material, dust and sand, is carried away by the wind and contributes to fill out some depression; greater material is brought down by the brooks and the rain water, and the result is that the ranges are growing lower and lower, the depressions higher and higher, and the relative altitudes diminish in the course of innumerable centuries. If one has seen the Sachu-tsanpo in the rainy season, dark grey with mud and silt brought down to Selling-tso, or a spring storm with the air absolutely full of sand and dust, one will easily realize the enormous work carried out by wind and water in the transportation of solid material. Once Northern Tibet was no doubt as accentuated as the Himalaya-it is the work of the atmospheric influences of geological periods that has given the country its present relief. Solid material has filled up all deep valleys and depressions, and denudation and transportation are still going on, and what we call a plateauland is a perfectly secondary phenomenon. Here the horizontal lines prevail, specially in Central 'Tibet; one has to go down to peripheral country to find vertical lines in the landscape. My panoramas will show how very level the land is as a whole, in the same way as the ocean seen from a ship's deck, even if the waves are as high as they possibly can be. The whole of Tibet is like a sea, the gigantic waves of which, driven up by northern or southern winds, have been changed into stone at the moment of their worst fury. On the ocean every ninth wave is said to be higher than the rest-in Tibet the case is the same; after a certain interval one comes to a mountain wave much higher than the neighbours. It is the 
tangential pressure in the Earth's crust that has forced those ranges to rise, and as the pressure has been stronger in the west, the ranges are here situated much closer to each other than in the east. They diverge from the enormous mountain knot of the Pamirs, and the distance between them becomes greater and greater to the east.

Time does not allow me now to enter upon the interesting question of a probable Ice-Age in Tibet, the curious distribution of the lakes, most of them being situated near the highest mountains, nor can I give now an account of the general meteorological and climatological relations-as I know them-the prevailing west and south-west wind being the most conspicuous and characteristic element. I will only say that, so far as my experience goes, it rains more in the east than in the west, but snows more in the west than in the east-that is to say, that Eastern Tibet gets most of its precipitation in summer, Western Tibet in winter. The fluctuation of the water stored in lakes and rivers depends of course upon the precipitation, and as this is diminishing all lakes are slowly drying up, although this may be only a periodical phenomenon. The abundance of grass depends also upon the rain, and as the prosperity of the flocks depends upon the grass, and the existence of the nomads, nay, the whole country, depends upon the flocks, everybody is looking out for rain, specially in July and August, which is the rainy season.

Of great interest it will be to draw on a map the boundaries of all the self-contained basins we know; they form a very curious mosaic on the plateauland, and their exterior boundary is the chief watershed of Tibet, in which the greatest rivers of Asia, except the Siberian and Aral rivers, rise. As to the heights, the data we possess are now so numerous, that it will not be difficult to make a general hypsometric map with the regions of different height in different shades of brown. The map illustrating this lecture gives only a vague idea of the general orographical structure. From 1200 different places on this journey I have taken specimens of rock with dip and fall, and from these a general geological map and geological profiles may be constructed. Every one of those sciences would give material enough for a separate lecture, and there is enough to do in Tibet for the explorers of the future, even if the period of important geographical discoveries is past.

But now to my journey. The red line is my journey of 1906-1908. It looks so nice and comfortable on the map, but in reality it is a very serious and difficult thing to cross the whole of Tibet from north to south. I left Leh on August 12, 1906, with the strongest caravan I have ever had : twenty-five Ladakis, ninety-seven ponies and mules, and thirty ponies hired for the first month. Of the animals only six came through. Dr. Arthur Neve had recommended to me a young Babu, Robert, who proved to be a very excellent help in several scientific observations and a favourite with both Ladakis, Tibetans, and myself. My noble friend 
of so many Asiatic years, Sir Francis Younghusband, had been kind enough to provide me with the very best caravan-bashi that could be got, Mohamed Isa, who had been with Younghusband to Mus-tagh and Lluasa, and was Ryder's and Rawling's caravan leader; he was at the side of de Rhins when he was murdered in Eastern Tibet, 1894, and he had an experience of thirty years of Asiatic travel. I shall never forget the great kindness with which H.H. The Maharaja of Kashmir, his private secretary, Daya Kishen Kaul, and, in Leh, Captain Patterson, helped me in every possible way to get together a really first-class caravan.

We went north-east over Marsimik-la, crossed the Karakorum east of Chang-lung-yogma, crossed Ling-shi-tang and Aksai-chin, crossed Deasy's, Rawling's, and Wellby's routes, kept east and east-north-east, and turned sonth-east between the routes of Bower and de Rhins. On the heights of the Buka-mangna range we lost nine mules in one day, but to the south the country became more and more hospitable, with plenty of grass and water. After eighty-three days' loneliness we found the first nomads, and then we passed black tents almost every day, and could buy yaks to replace our dead animals. We left to the east the lake which de Rhins calls Ammoniac lake, continued straight south to Bog-tsangtsangpo, which I fullowed a couple of days to get a connection with my map of 1901, turned again south-east, crossing two considerable ranges; from one of them just a little bit of Dangra-yum-tso could be seen to the south. We reached Ngangtse-tso on December 28, and here appeared my old friend, Hladje Tsering, with a little escort to stop me. The first day he told me I could never proceed in this direction-I had to leave Naktsang territory at once and go north or west; but the next day he gave me permission to continue towards Shigatse. I have never been able to understand why Hladje Tsering changed his mind, but I have heard that this cost him his place and rank. Perhaps it was wrong of me to expose him to such a great risk, but I believed he had got some secret order during his stay in my camp, and he probably believed I had got some private permission to visit Shigatse. Moreover, my geographical morals are quite different to my ordinary morals, and if I can possibly make any geographical discoveries-I go on. And on we went south-east, crossing six passes. I really do not know why I hurried on this time much quicker than usual, without stopping anywhere and making very long marches. It was as if some invisible force had pushed me on, and even when we reached Ye-shung, on the northern bank of the Tsangpo, where several great gunpas were a strong temptation to visit, I did not stop, but hurried on to Shigatse, and entered the city late in the evening of February 9, 1907. On the 11 th, in the morning, arrived one lama and one official from Devashung; they told me news had reached Lhasa from Hladje Tsering, and at once they were sent with a little force to Ngangtse-tso to stop me and force 


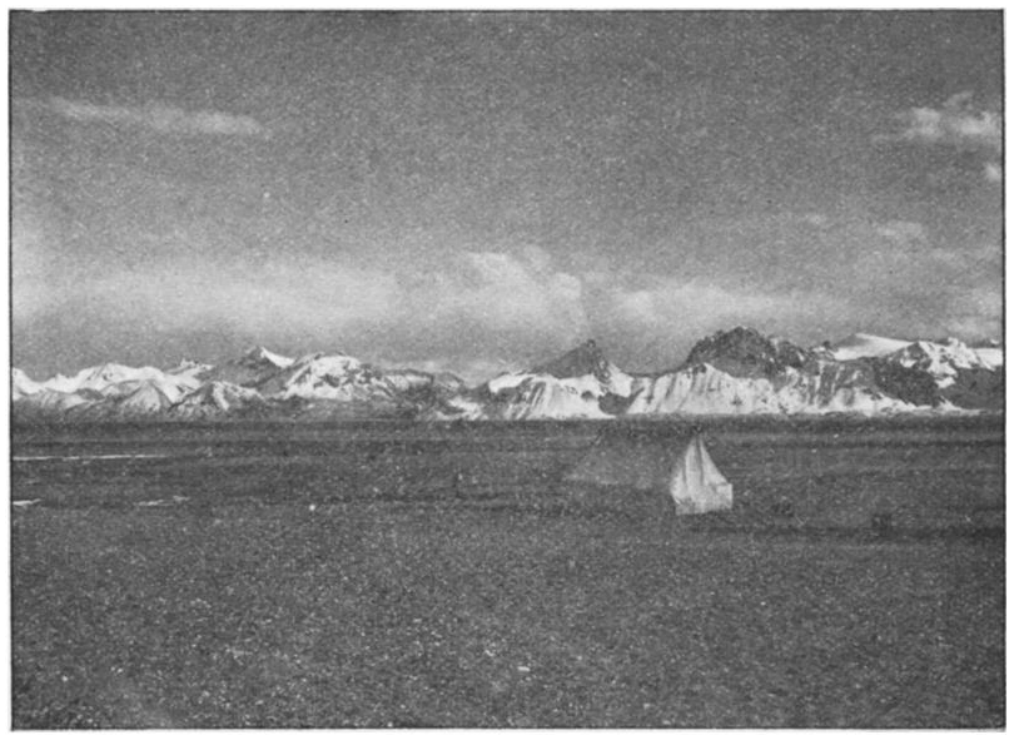

MOUNTAIN RANGE IN NORTH-EAST TIBET,

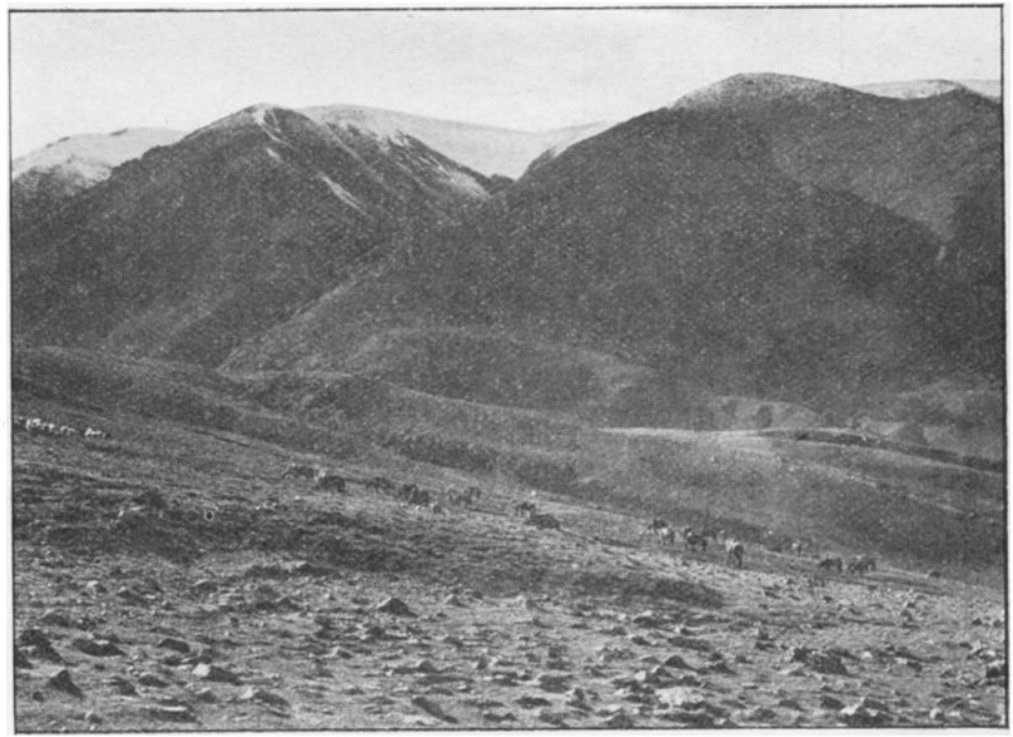

MOUNTAIN SCENERY, NORTH-WEST TIBET. 
me to return. And when they heard I was gone, they burried on in my steps and reached Shigatse a day and a half after me. If $I$ had travelled just a little slower I should never have reached the town, never seen Tashi-lunpo and the Tashi Lama.

The most important geographical discoveries on this line from Ngangtse-tso to Shigatse were the very high mountain sytems we crossed in Se-la, and south of it the complicated river system of My-chu, which joins Raga-tsangpo one day above its junction with the Tsangpo, and is one of the greatest northern tributaries to the upper Brahmaputra. When I stood on Se-la, and in a biting January gale sketched a panorama of the whole horizon, and later on after having crossed this complicated world of enormous mountains and this labyrinth of deep wild valleys, I understood that this range could not possibly be anything else but the western continuation of the mighty range which is situated on the southern shore of Nam-tso or Tengri-nor, the highest known summit of which is Nien-chen-tang-la. So when I wrote to Major O'Connor I proposed to call the whole range Nien-chen-tang-la.

The eastern part of this range was for several years fairly well known. It was known to be a watershed between the Salwen and Brahmaputra. The famous pundit, A.K., had crossed it in 1881, probably in Nub-kong-la. Abbé Huc and Abbé Gabet had crossed it in 1845 in Shang-shung-la, which again had been taken by A.K., and which for centuries has been crossed by innumerable Mongolian pilgrims with the same feelings of exaltation as the Mohammedan pilgrims pass Mount Arafat on their way to Mecca.

Further one step westward we have the pass Dam-largen-la crossed by the admirable and noble pundit, Nain Singh, in 1874, and just west of Nien-chen-tang-la there is Guring-la, crossed by Littledale on his memorable journey, 1894-95, when he was forced to return the same way. Guring-la and Dam-largen-la are important from a religious point of view. Many pilgrims every year wander round Nam-tso, and some of them include Nien-chen-tang-la in the ring, thereby walking over the two passes. Several gunpas are situated on the shore of this the greatest lake of Tibet. Three journeys round the lake absolve the pilgrim from all his sins and make him sure of a happier existence when he will be next re-born. Then follow Tsebo-la and Shugu-la, of which I have got only verbal information, and finally the last hitherto known pass to the west, Kalamba-la, crossed by Nain Singh in 1872 . So far the geographical and orographical situation of this range was known before, when I crossed Se-la and could thus draw the range some 100 miles further to the west. I suspected already that this range continues far, far to the west-north-west, and Major O'Connor told me in a letter from Gyantse that he had long suspected the same thing, partly from the reports of pundits and partly from verbal information he had got in Tiket, and he proved to be perfectly right. 
But what did we really know? Nothing, or next to nothing! Did the geographical literature of any time or any country contain a word about this range except some meagre hypothesis? No, nothing! Nain Singh had, followed the Brahmaputra valley up in 1865, and so did Ryder and Rawling, Wood and Bailey, on their journey to Gartok, which has given to geographical science the best and most accurate map that ever has been made in Tibet. But from their route in the Tsangpo valley the head range cannot be seen from a single point, as I found afterwards by my own experience. One sees several gangris, or mounts, with eternal snow and ice, but one does not see the head range, or rather watershed, itself, and one has not the slightest idea of the very complicated architecture further north. Verbal information will lead to nothing, as I found. I asked people, especially merchants, who had been up to the north for years every year, and got them to tell where they camped, where they went over passes, where lakes and rivers were situated; but when I tried to get some certain conclusion the result proved to be hopeless confusion. I do not know what Major Ryder believed of the country to the north; probably he believed it was a high plateau-land, the highest ridge or range of which was situated about $31^{\circ}$ N. lat., and where Chachu and Charta-tsangpo had their sources. The southern boundary of this plateau-land he probably thought was formed by a border range, several peaks of which he measured, and which he regarded as broken through in transverse valleys by the two considerable rivers mentioned above. I believed, as I have explained in the fourth volume of my last scientific work, that it was a highland with two ranges parallel with the Tsangpo, and $I$ had arrived at this conclusion from Nain Singh's lakes, those which he had heard of but not seen; but it all proved to be perfectly wrong. How little we really knew of the country-" the Dokthol Province," a name absolutely unknown to the natives-is shown also by a letter I got from Captain Rawling, in which he expresses the theory that the great northern tributaries of the Tsangpo come from the Central Lakes, discovered by Nain Singh, and exactly the same theory is found in Sir Thomas Holdich's excellent book, 'Tibet the Mysterious,' which was published after Ryder's and Rawling's expedition. So all of us who had specially paid attention to this problem, knew absolutely nothing of the country, and we lost ourselves in hypotheses of very little value, as they had no real foundation.

But first let us leave Shigatse. I stayed six weeks there, or rather in Tashi-lunpo, where I spent the whole time. The Tashi-lama, or Panchen Rinpoche (Banchin Bogdo, as he is called by the Mongolians), is one of the most remarkable and fascinating men $I$ have met in my life, and I shall never forget the great hospitality and kindness he showed me as long as I was his guest. I arrived just at the Losar, or New Year's festivals, and was invited to every day's play. 


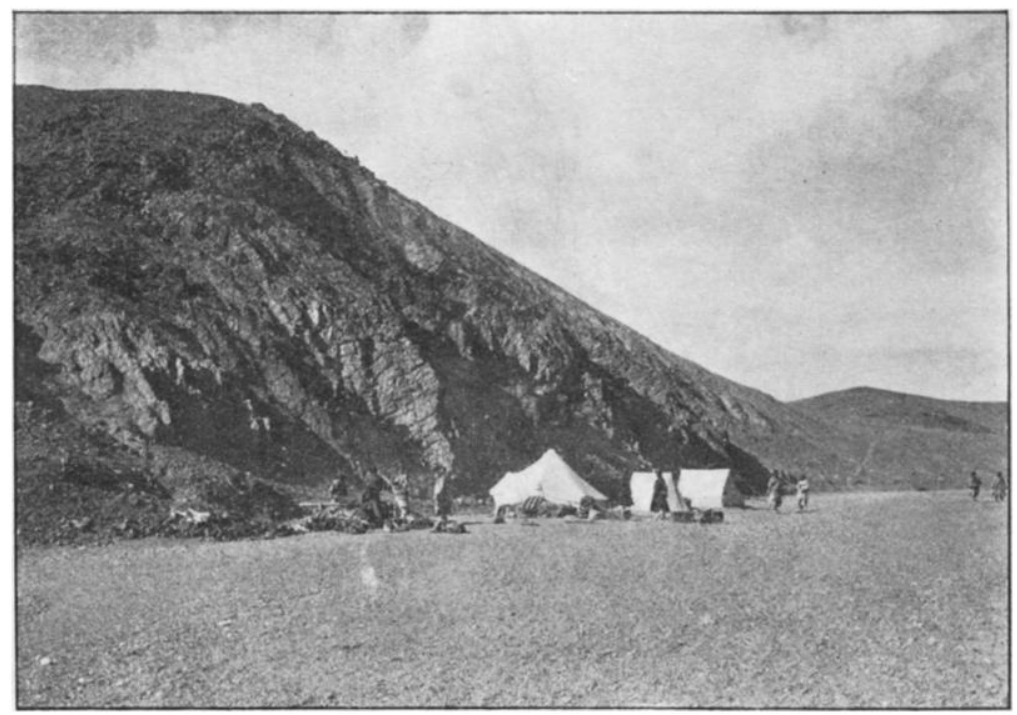

ONE OF OUR CAMPS, CENTRAL IIBET.

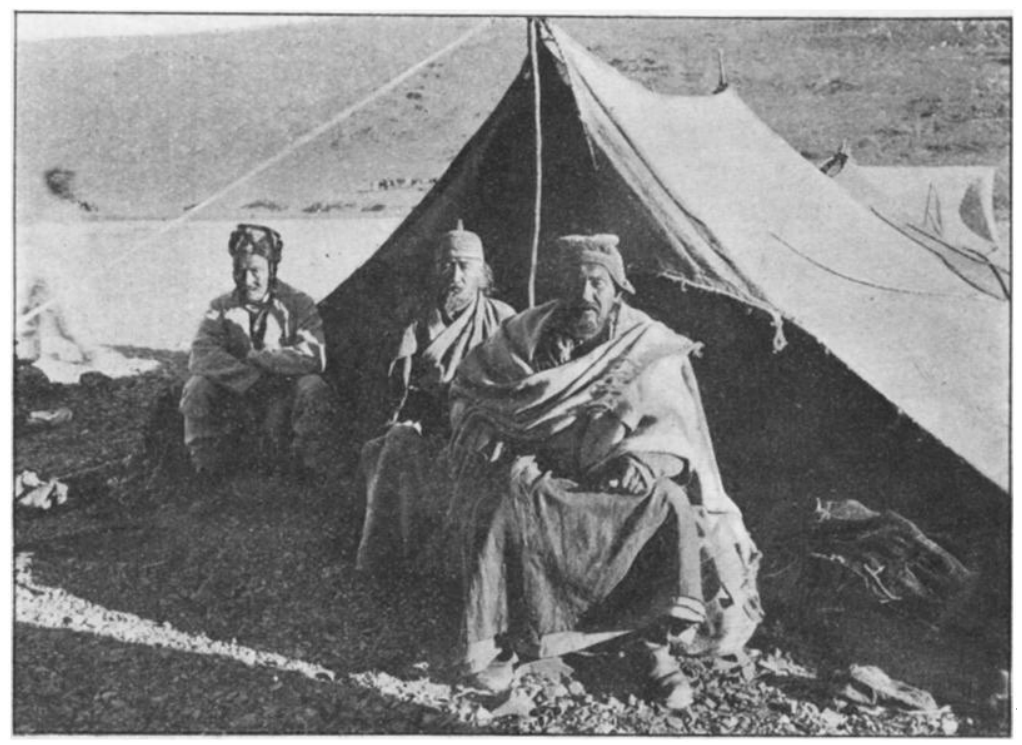

MOHAMED ISA AND TWO LADAKI CHIEFS. 
How very wonderful and picturesque it all was. The Losar hymns of Tashi-lunpo made a deeper impression upon me than even the Church music in Kasansky Sobor in Petersburg, or Uspensky Sobor in Moscow. They are full of faith and longing, of mysticism and harmony, and they lead the listener away to the land of dreams and hope. To begin with, they go in crescendo and then in diminuendo as far, far away as if the singers were already at the gates of Nirvana.

During my stay in Shigatse I made acquaintance with another man whom I shall never forget, Major O'Connor, although I never met him personally; but we were in very lively correspondence, and he gave me any amount of valuable information and advice. The Chinese High Commissioner, Thang Darin, and the Amban of Lhasa, Lien Darin, were extremely polite and kind in their letters to me; they probably wished me to go to Gyantse, as it would be easier to get me down to India from there. But I did not go to Gyantse at all. The Tibetan authorities of Lhasa seemed not to know at all what to do with me. They have hardly made acquaintance with anybody who has been so difficult to get rid of as me-except Younghusband, of course. One day in Shigatse I got three big boxes from Major O'Connor. They contained a whole library of books and all sorts of most delicious tins, cakes, biscuits, wine, liquors, and champagne. Imagine me drinking champagne quite alone in my tent in Tibet. Every day in Shigatse I proposed O'Connor's health at my lonely dinner.

As to the ambassadors from Lhasa, who had to deal with me as to which way to return, I would not tell them openly that my wish was to take some northern road where I could study the great range of Nienchen-tang-la further to the west. I thought they would be suspicious, and stop me altogether. But I managed to get permission to take the Raga-tsangpo road, and from there the escort took me up over the head range again, which I crossed in the pass Chang-la-Pod-la, and thus I got some 50 miles more of the western continuation of the range.

Now it was my intention to go to Dangra-yum-tso, discovered by Nain Singh, and by help of some rupees the escort agreed to take me down there. As I have said, my geographical morals are a funny sort of thing, but well-they give me their lakes and mountains, and I give them my rupees, and both parties are extremely pleased and satisfied with each other; but for them, of course, it is a risk. Now this time, when we were two short marches from the lake, and it could be seen in the north as a thin blue line, I was stopped by a force from Shansa dsong and made to go down to Raga-tasam. But I had fixed the situation of Targo-gangri, Targo-tsangpo, and Sershik-gumpa, all three heard of but not visited by Nain Singh. And I had discovered Shuru-tso, a rather big lake at the very northern foot of the head range. And now I crossed this range again in Angden-la, continuing it some 60 miles 
further west. In Raga-tasam I touched Ryder's and Rawling's route for the first time since Shigatse.

Dangra-yum-tso is much too big on Nain Singh's map, and his Mun-tso, two small lakes, are situated not south but west of southern Dangra-yum-tso. Both Targo-gangri, one of the most magnificent snow mountains with glaciers I have seen in Tibet, and Dangra-yum-tso (or Dangra, as it is usually called) are holy; it is exactly the same combination as Mansarowar and Kailas in the west, and Nam-tso and Nienchen-tang-la in the east. It takes the pilgrim five days to go round the lake; the water is slightly salt, but they drink it anyhow, as it is holy, and a man or a pony who has drunk of it will for ever be safe from wolves and robbers and sickness. At the eastern foot of Targo-gangri, one day south of the lake, is Sershik-gunpa, a comparatively rich templemonastery. The lamas belong to the Pembo sect. I do not know exactly the difference between the Pembos and the orthodox, but when the orthodox say, "On mane padme hum," the Pembos say, "On mate moti sale do," and they hate each other heartily. As the Greek Catholics make the sign of the cross from right to left, whereas the Roman Catholics do it from left to right, so the Pembos have the little funny peculiarity of turning their prayer-wheels the wrong way, and both, of course, believe the other will burn in eternal fire, or, at any rate, be re-born in a very poor and miserable form of existence.

From Raga we went to Saka-dsong, leaving the beautiful snowmassive of Chomo-uchong, or "The High Nun," to our left. In Saka Mohammed Isa died, and was buried strictly after the Mohammedan ritual. One year later some Tibetans told me that ghosts were haunting the grave every night, and from the interior of the grave one heard mysterious sounds and sighs, so nobody dared to come near it.

Several times I tried to get permission to go north to see more of the great range and the country north of the 'I'sangpo, but always in vain; once we tried to slip over, but were stopped by Bongba men. I wrote to Lien Darin and Thang Darin with special mail-runners. Lien replied, certainly I could take a northern road if I liked; but I got his letter three months too late. Thang said he could under no conditions let me go to the north-west, "as both people and country are wild there." I wonder how he knew that. It was really hard to go further and further west, and to leave more and more of the great unknown country to my right, because this patch north of the upper Brahmaputra was the greatest white patch in Asia, with only one exception, a part of the Arabian desert.

The Gova of Tradum, a great scoundrel, but one of my best friends in Tibet, let me go south over the Tibetan frontier and down into Nepal. The Himalayan watershed pass one crosses here * is only about 300 feet

* Kore-1a. 


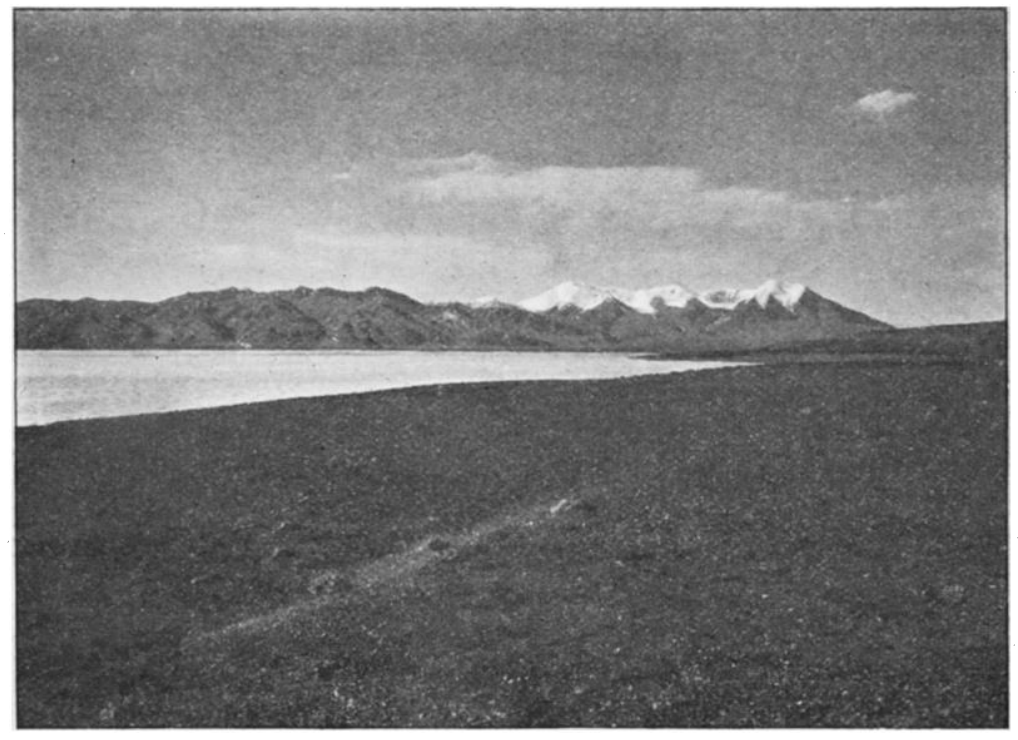

A LAKE IN CENTRAL TIBET.

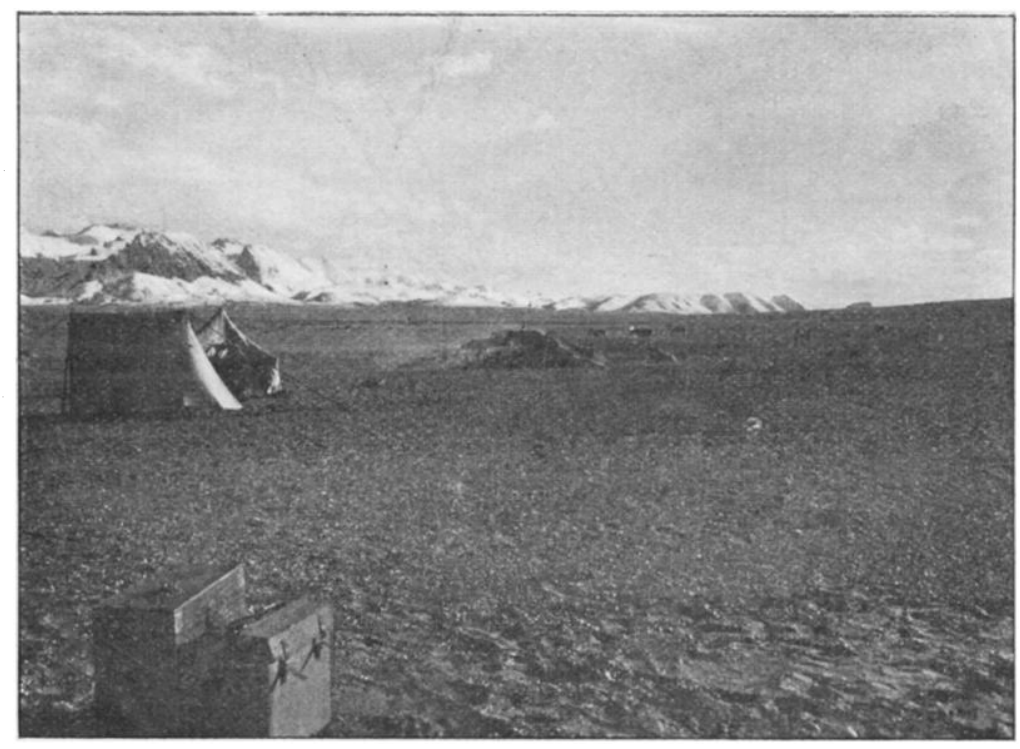

ON THE SHORE OF LAKE LIGHTEN.

This content downloaded from 198.91.37.2 on Mon, 27 Jun 2016 03:22:10 UTC All use subject to http://about.jstor.org/terms 
above the Tsangpo, and it should be an easy matter for modern engineering to dig a channel and force the upper Brahmaputra to become a tributary to the Ganges, although I really do not know if northern India would become more happy for that; the Tibetans would be awfully angry, that is sure.

The next problem that interested me specially was to find the source of the Brahmaputra, and I have described in a short note how this trip was successfully carried out, so I will not take up time with it now. It was a proud feeling to stand at the three-headed source of the magnificent river that goes out in the ocean near Calcutta, Brahmas son, famous in the ancient history of India. But perhaps it was still more wonderful, some time later on, to camp over a night at the little rock from which the Indus comes out as an abundant spring, growing bigger and bigger on its adventurous way down through the mountains, singing its eternal songs between the rocks, the same melodies as in the Macedonian's time. I had a feeling as if the fate of my own life through this river in some little way got counected with his, although 2200 years lay between us and sans comparaison, of course. But all this, as well as the interesting question of the watershed between the Brahmaputra and the Sutlej, and how the Sutlej still, although underground, comes from Mansarovar and Rakas-tal ; further, my adventurous navigation days and nights over those two lakes, my pilgrimage round the holy mount of Kailas or Kang Rinpoche, and my journey up to Yumba-matsen. and down to Gartok-all this has to be left to my next book.

The two passes Lachen-la and Jukti-la, which I crossed on this trip, are situated in the very considerable range which stretches north-west to south-east, one day north of Mount Kailas, and which I was almost sure was the same range I had crossed in Se-la, Chang-la-Pod-la and Angden-la. Between Jukti-la and Lachen-la are Dopchen-la and Hle-la, and west of Jukti-la several easy passes-for instance, Pema-la. At Chang-la it has been crossed by innumerable explorers and hunters. The Indus follows the south-west foot of the range the whole way to Gilgit, and the range goes through Ladak, Baltistan, and Chitral, and seems to be in very near relationship with the Hindu-Kush, thus going through Afghanistan also. But here was the weak point: it had never been proved that this western range was uninterruptedly one and the same as the eastern one south of Tengri-nor, and when I had come so far, I would give my life to solve this beautiful problem, which might certainly be called the most important and magnificent geographical problem still left to be solved in Asia. But when I reached Gartok I was far from the definite solution. Between Angden-la and Lachen-la I had left a gap some 300 miles long, and of this gap I knew nothing, although I and Nain Singh were the single explorers who had gone round it. Only step by step should I be able to understand and to penetrate No. IV.-APrIL, 1909.] 
in to the very soul of this gigantic world of mountains. It takes timeof course it must take time to digest such an enormous lot of stone as this mountain system. It can be done only successively and with an angel's patience. Every new pass over the head range will make the complicated orography clearer and open new perspectives.

Well, when I arrived in Gartok I was sure I could not leave Tibet without having crossed the unknown country at least once. If I succeeded in this, it was my plan to reach India viâ Nepal. And so we began to try and demoralize the younger Garpun (the other was sick) in the most horrible way. The great Ladaki merchant, Gulam Razoul, to whom the Garpun is in debt for big sums, tried all possible ways to get permission for me to go eastwards into the unknown. He said that when our animals died we had been obliged to bury some precious boxes somewhere to the east, and had to go and fetch them now, which was, of course, a formidable lie, as we had not lost so much as a box of matches; but the Garpun replied that he did not care a bit for my lost boxes, and that it was more important for him not to lose his own head, which he was sure of if he let me go into the forbidden country. Then Gulam Razoul told him I should give him two thousand rupees if he let me go, but he answered dramatically: "If this house were of solid gold, and he gave it to me, I should not take it; if he tries to slip over to the east without permission, I will send armed men to catch him." So he was too strong for us, and I had to think over a quite different scheme.

I decided to go round again and to enter the Chang-tang from the north, and cross the whole of Tibet diagonally once more. I knew it was a matter of half a year to reach regions which were only one month from Gartok, and this half year was the winter. But now, of course, the Garpun was suspicious, so much the more as he saw me buy twentyone Tibetan mules from Gulam Razoul.

From Gartok we sent couriers to Gulam Razoul's father in Leh, old Haji Naser Shah, to arrange a quite new complete caravan for me. He would even provide me with new men; not a single man of the first set should follow me, as they might have been recognized later on. When I reached Durguk, November 30, 1907, the new caravan had arrived the very same day, and everything was ready.

In Gartok I had told everybody that I was going to Khotan and Peking. Even Haji Naser Shah and the new eleven men believed this was the plan. I went so far as to send a telegram to Reuter about Khotan. It was quite necessary that nobody should suspect anything else, because Rudok-dsong has spies in Ladak, specially one in Durguk, and if he should have got the slightest suspicion about the real plan, we should have been stopped somewhere north of Rudok. My new caravanbashi, Abdul Kerim, was a perfectly honest man, but the greatest ass I have ever met. I ordered him to take corn for the animals for three 


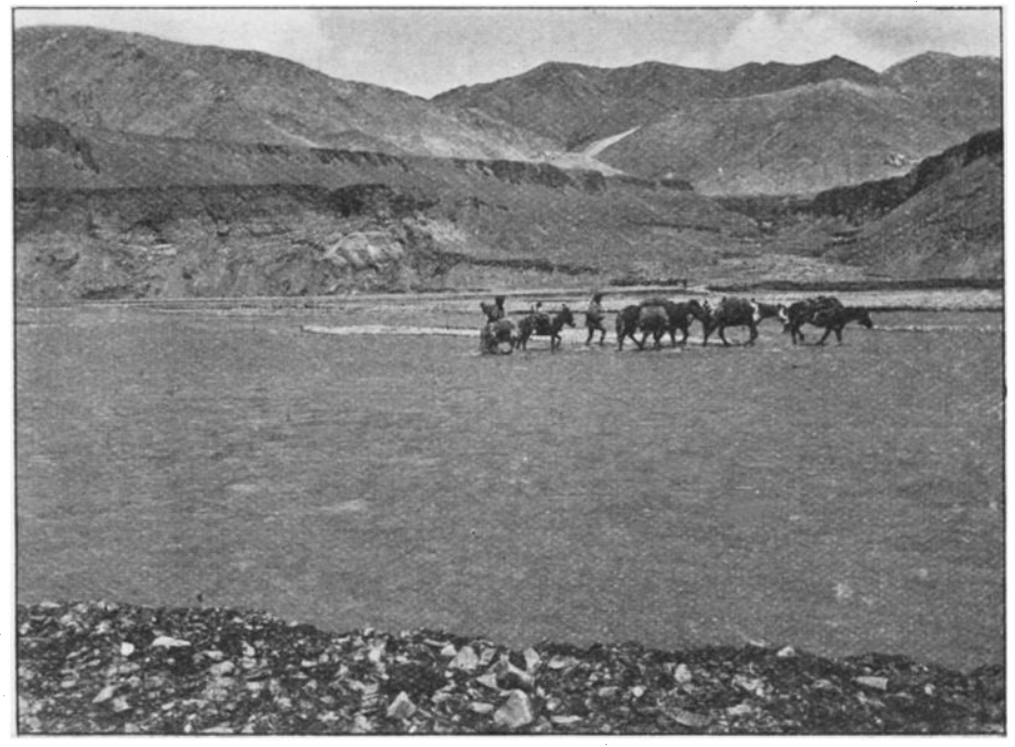

CHANG-CHENMO.

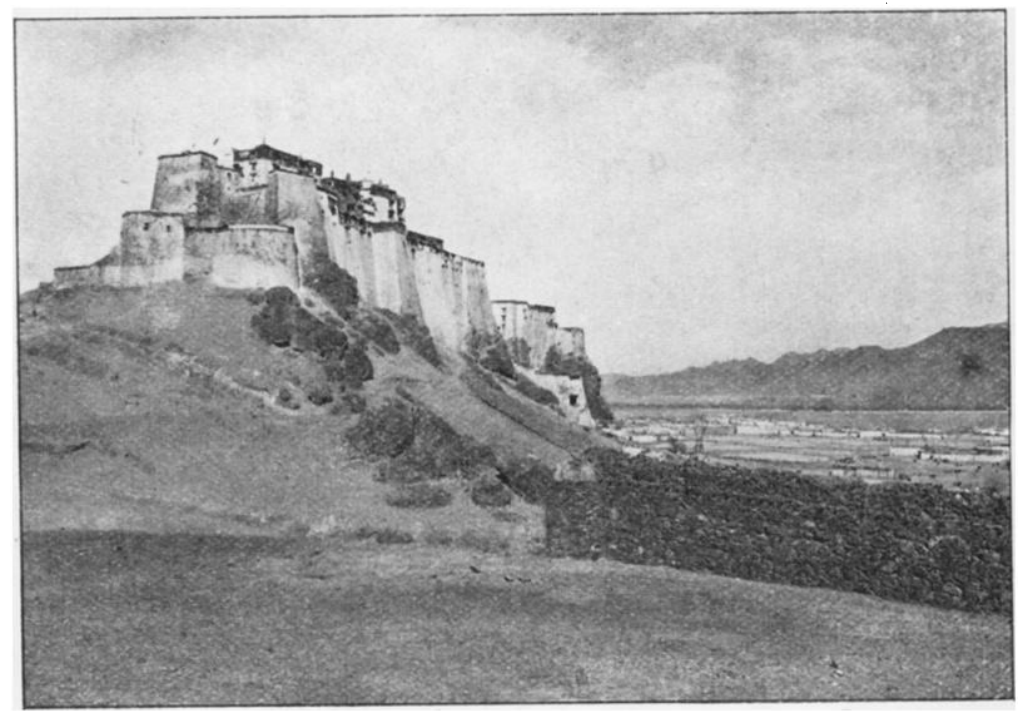

SHIGATSE-DSONG. 
months, but as he was sure we should go to Khotan he took corn only for twenty-one days. For the men, fortunately, he took five months' provisions as ordered. I had one little tent, the men two bigger. My luggage was reduced to a minimum, three boxes only; amongst their contents there were two complete Ladaki dresses, as it was my intention to travel in disguise as a Ladaki merchant as soon as we came across natives. Only three ponies, two mules and one dog were veterans from the first journey. Perhaps somebody might recognize them. Oh no, they were all dead long ago, when we met the first Tibetans. All the rest, men and forty animals, were new.

We left Durguk on December 4, and it was a hard journey that began now, the hardest I have ever made. We penetrated deeper and deeper into the heart of Asia, but also in to the heart of a new winter, and a winter on those enormous altitudes. From sheyok we took a man, who had to look after our twenty-six sheep; and as he was a new addition to the caravan we became thirteen-but we were not superstitious. We met several caravans from Yarkand. One of them was a perfect wreck, and had lost fifty-two ponies on the road. In one caravan I met my old servant, Mollah Shah, who was also with Littledale, and now he had not been to his home in Cherchen since he left me in 1902-what a wonderful life of wanderings and struggle they live, those Asiatics. Most of the Yarkandis advised me to wait till spring, as the Karakorum pass was very bad. The whole way is full of dead ponies. At one place, during two hours' ride, I reckoned sixty-three. Some of them looked as if they were taking a rest only, some were half-buried in snow; the dogs barked at them until they got accustomed to see them. At several places we passed heaps of boxes and big packets of silk left by caravans that had lost all their animals-it is like ships baving to throw all their cargo overboard when they begin to sink. It is a real Via Dolorosa; those grey granite rocks could tell no end of sufferings they have witnessed; in the night one thinks one can hear the sighs and heavy breathing of an endless carnival of animals, the veterans not able to walk any further.

The Karakorum pass can never be improved-it is the absolute height that kills. But in the Sheyok valley, where the road crosses the half-frozen river twenty-five times, something could be done. It may be strategically wise to leave the bad boundary roads as they are; but trade with Eastern Turkestan suffers from it. .In the Durguk valley a couple of dynamite cartridges would improve that horrible road immensely.

We passed a man who had been abandoned with both hands and feet frozen on the Karakorum; the fingers were literally falling off. $\mathrm{He}$ said he was creeping down to Sheyok. We gave him bread, flour, matches, and some rupees. In the nights the moonshine was brilliant, the mountains stood like black coffins on both sides of the valley, with 
the blinding white snowfields over them. A lonely raven followed us for a month; I hate them; they only wait in case somebody may be left behind. But on December 16 the caravan got an additionfour puppies; two were drowned, one died the very day he opened his eyes to get a glimpse of this cold mysterious world; but the last one came with me to Simla.

At Burtse, where the cold went down to $-35^{\circ}$ C. ( $63^{\circ}$ of frost Fahr.), I made the first discovery during this journey-only eight days' corn left. To return to get more had been to spoil the whole plan. I was quite prepared that all the animals should die, and we should have to go on foot as far as we could. Now just here a big valley from the east seemed to invite us ; if we found a road here we should save several days. A man was sent up and reported that the way was excellent, so we went on and marched the whole long day to a point where the valley was so blocked that hardly a monkey would have been able to continue further. The country was absolutely sterile. In the night the animals were kept tied up; they ate two sacks and most of their ropes. So the next day we hurried down the same way; we had lost three precious days, all were tired, and the situation looked rather hopeless. Mohamed Isa's pony from Shigatse was the first to die; he looked tired and done for where he had fallen in the snow; he seemed to need a long, long rest. The raven at once pecked out his eyes. Now our sheep began to die of cold, height, and fatigue. On the evening of December 23 , in the ravine Kisil-unkur, the men, eight of whom were Mohammedans, began to sing a rhythmic and melodious hymn to Allah, praying him to let us cross the Dapsang without a snowstorm. And still nobody knew my real plan. So they were rather astonished when I, the next day, gave orders on the heights of Dapsang to turn straight east. We left the Karakorum pass to the north, went over the range by another pass, and the whole day we ploughed a track through deep snow. The night came down over the enormous snowfields, biting cold; the temperature went down to the freezing point of mercury ( $-38^{\circ} .6 \mathrm{C} ., 69 \frac{1}{2}^{\circ}$ of frost Fahr.). I had two candles and a nice fire in my tent, as it was Christmas Eve. The next morning one pony lay dead and hard on his place amongst the rest.

And now our difficulties began. The Mohammedans were constantly singing prayers to Allah, with their eternal "Allahu Ekber" and "Allhamdulillah rabel alahmin errahman errahim." I understood they were afraid and regarding the situation as specially serious. The ordinary profane songs of Ladak had long ago frozen away on their lips. Orer comparatively open land we kept east. No grass at all, but where burtse and yapchan plants grew we used to camp. Not a drop of water; the animals had to eat snow. The corn was finished, and rice and flour from the men's provisions given to the animals-we only took care that a supply for fifty days should be kept aside.

In the beginning of January we lost ourselves in a labyrinth of 
mountains, passes, and deep valleys, all belonging to the Upper Karakash-darya, going down to Eastern 'Turkestan. On January 11 we camped at the very same point as last year, on the shore of the Aksai-chin lake. It was like a funeral procession; every day took a mule or a pony, sometimes two. All boxes, books that were read, and other unnecessary things were used as firewood. In the night of January 15 the cold was $-39^{\circ} \cdot 8 \mathrm{C} .\left(71^{\circ} \cdot 6\right.$ of frost Fahr. $)$, the lowest I have ever read. During the periods of intense continental winter cold we had fortunately no wind to talk of. Ovis Ammon and Orongo antelopes were numerous now, and once our hunter killed two, and the two last sheep were spared for a time. On January 18 we had lost one-fourth of the caravan; the next day we found the first signs of Tibetan hunters, and on the 20th a hard storm killed two animals, one of which was the last mule I had bought from the Rajah of Poonsh. Now began a storm that went on for weeks without interruption and killed all our weaker animals On January 26 we crossed Arport-tso on the ice, which was covered with snow, green and clear as glass. Two days later we lost three animals, and the last sheep was killed.

On the following days heaps of snow came down; we proceeded hopelessly slowly through 2 feet of snow, sometimes 3 . Nothing could be seen; the first ponies and mules in the caravan disappeared as phantoms in the snow-drifts. At the western end of Shemen-tso I thought we should be snowed up for the rest of the winter. It snowed day and night; walls of snow gathered round the tents; it was more like a Polar expedition. The storm continued as before. We followed the northern shore of Shemen-tso. On February 5 sixteen animals out of forty were left. Once more everything that could be spared was burnt. We had no meat left, and almost all rice was given to the last animals; it was necessary to make the loads lighter. The next day one mule and one pony died.

On February 8 we passed a trap with an Orongo antelope in it, and all were happy to get meat. Of course this was a sign that hunters were near, and later in the day we found two tents, and could buy a couple of sheep, milk, and butter. During sixty-seven days we had not seen a man. Now all my European clothes were burnt, and I appeared in disguise quite like the other Ladakis. On February 15 we crossed the Karakorum range again, which killed three of our animals, amongst them my riding pony, which had carried me faithfully through so many adventures for one and a half years, and saved me when once a wild yak was very near to take both him and me on his horns. It was more hard than I can tell to lose him. On the other side we passed some gold-mines. And so we left Deasy's and Rawling's routes behind us, passed Lemchung-tso, always in storm, and entered new country. Again, since a couple of animals had died, several things were burnt or thrown into Lemchung-tso, even some thermometers, clothes, boots, 
belts, etc. February 24 we had still three ponies and seven mules, one-fourth of the caravan, left. Two days later great goldfields again. The 29th we reached Lumburringmo-tso, where the Senkor nomads said that never had any Ladaki merchants passed through Chang-tang, least of all in winter, and that we had a European hidden amongst us. We stayed two days with them, got friends, and bought twelve sheep for loads. For several days the storm was so hard that it was impossible to move.

On March 7 we camped on the bank of a river going southwest and frozen all over. One mule died, and the two dogs stayed with her to get a nice meal-they were never heard of afterwards. The storm made it impossible for them to follow our footsteps. As one of them was my special favourite since Srinagar, I felt quite lonely in my tent since she was gone. Now we had only the threemonths'old puppy left. During the five journeys I have made in Asia, the first in 1885-86, I have had hundreds of servants, and I have forgot many of them. But I have not forgotten a single one of the dogs; they stand before my memory as clear and alive as if $I$ had left them yesterday. And it is always more difficult to say good-bye to the dogs than to the men; the men go home to their friends and families and will be quite happy, but the dogs have no home and nobody to go to, and nobody will be kind to them afterwards, and when I leave them they look after me with long wondering melancholy eyes, and I cannot possibly take them all home with me; I should have a real exhibition of Asiatic dogs by this if I did. Once I took a dog from Lop the whole way to Peking, through Mongolia and Siberia to Petersburg; but as it was forbidden by that time to take dogs over from Russia into Sweden, I had to give him to a friend in Pulkova. But there he almost killed half a dozen old women and every cat within a radius of three miles. So my friend gave him to a peasant, with whom, I suppose, he continued his wild Asiatic robber life.

And so we reached the district of Nagrong, with two stone houses and a big temple tent belonging to the Gertse Pun. From here the ground was excellent, an open latitudinal valley, but there was still much snow, and the storm went on. March 16 we camped on the shore of Tong-tso, and now we passed tents everywhere and could buy sheep and a couple of yaks. I had to paint my face and hands black every morning, but I could never get so dirty as the Ladakis. So we turned south, leaving the beautiful gangri Shakangsham to the east, crossed two small passes, and heard of Karma Puntso, the Governor of Bongba-it was critical to be so near to him. Once we bought a pony and a big dog, Takkar, wild as a wolf; he soon became our friend and favourite, and was quite mad with fury at every Tibetan he saw. The following days we went through a real labyrinth of mountains stretching east to west, crossed Kangsham-tsangpo, Chaklam-la, 


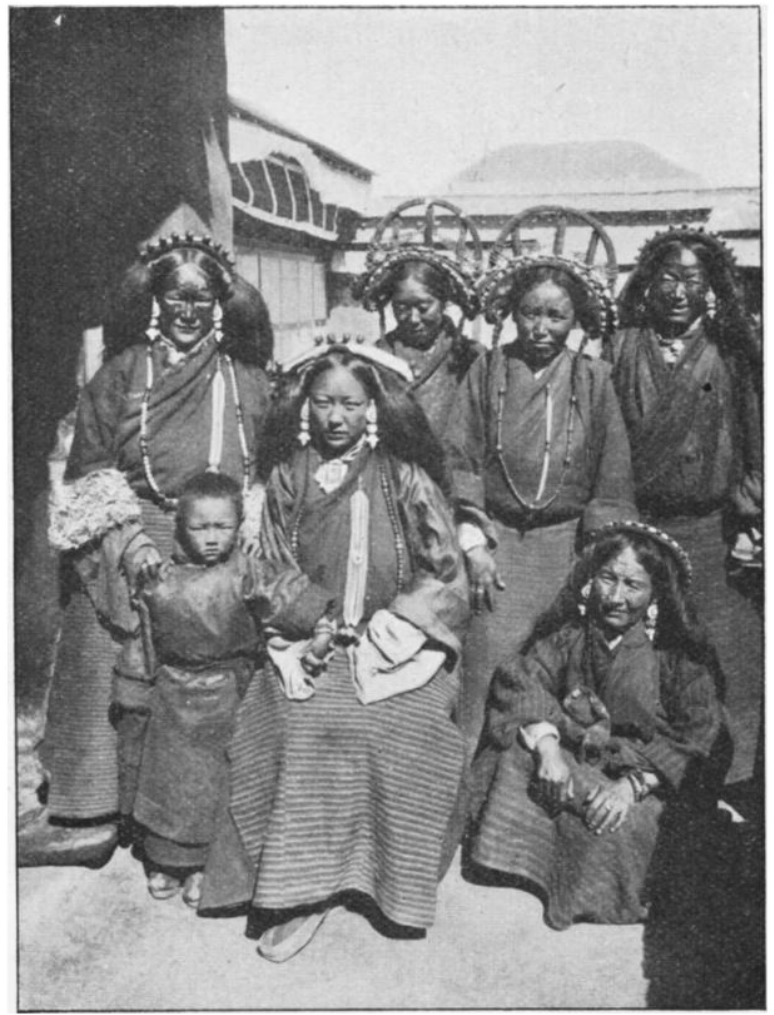

THE BROTHER AND SISTER-IN-LAW OF THE TASHI-LAMA.

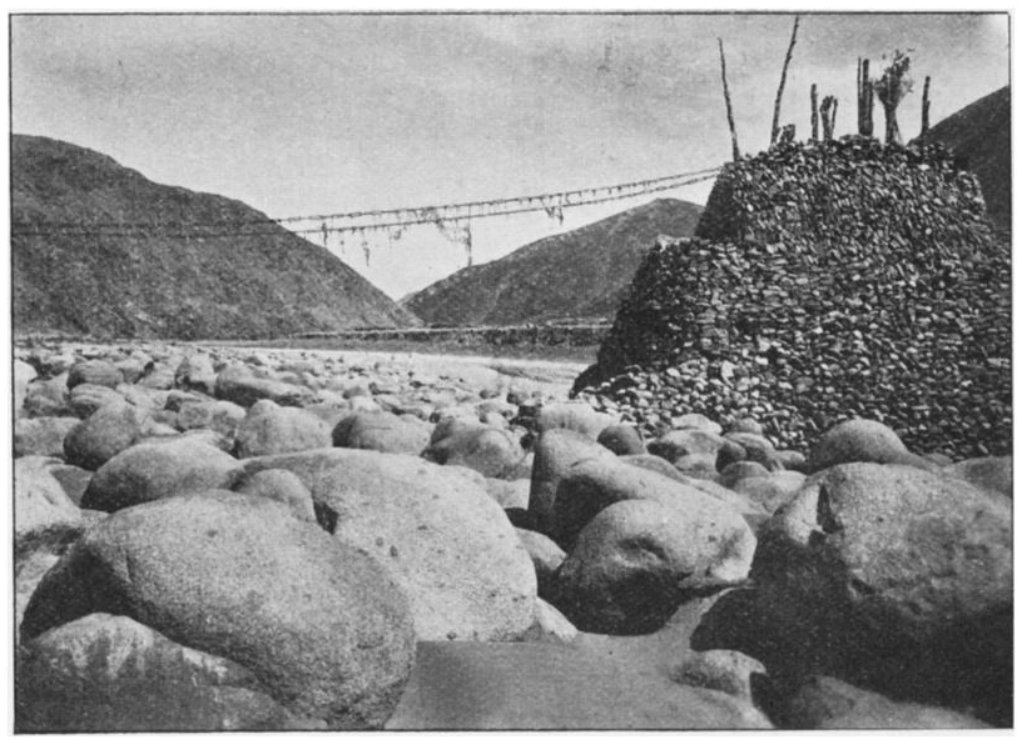

THE BRIDGE OVER THE TSANGPO NEAR PUN-TSO-LING. 
Sangchen-chu, Sangchen-la and Ladung-la. Our caravan consisted now of two ponies, three mules, two yaks, and twenty-five sheep, all under loads. And so we met the great merchant, 'I'songpun Tashi, who stays here over the winter selling tea to the nomads on credit; in the summer, when they have sold their sheep wool, they pay their debts. He came to pay us a visit, and as he seemed very interested in our tents and their contents, Abdul Kerim cried to Kutus, one of my Ladakis, and Haji Baba (that was me) to go and eatch a pony that had run away in the mountains. T'songpun Tashi is a powerful man from Lhasa, and it was nice to come away from him without any further adventures. In three days we passed thirty-two tents, and I had to go on foot and drive the sheep. On April 1 we crossed Satsot-la and came down to Chunit-tso, and followed its western shore for one day; here we met a great salt caravan from Tabie-tsaka, from which most of central and eastern Tibet get their supply of salt. Always keeping straight south we went over Nima-lung-la and reached the district of Kemar with several tent villages.

One of the mighty head ranges north of the upper Brahmaputra is now visible beautifully with great snowfields and glaciers. Turning southeast we had the magnificent Hlunpo-gangri to our right for several days, and for six days we fullowed the big river Buptsang-tsangpo up to Samje-la, situated in the watershed, and now it struck me that only Trans-Himalaya was the right name. So I had controlled the existence of the system some 110 miles further west from Angden-la. It was an agreeable feeling to go down along rivers reaching the Indian ocean, the Samje river, the Rukyok-tsangpo and Chaktak- (not Charta, which is wrong) tsangpo. We met and passed several salt caravans to and from Tabie-tsaka; one of them told the authorities of Saka-dsong that they had seen Ladaki merchants on a very unusual route.

It was my wish to see as much as possible of Chaktak-tsangpo and the gangris from which it gets its great volume of water, and so I went, like a thief behind the mountains which are seen from the "tasam," following Chaktak-tsangpo, leaving it to the left where it comes from a valley in Kanchung-gangri, followed its left tributary Gäbuk-chu to the east, and reached an enormous tent belonging to two brothers, Kamba T'senam and Panchor. They were kind, sold us provisions, sheep, and a pony, and would show us the road over the two passes, Gebuk-la and Kinchen-la, as they said it was impossible to find the road in that labyrinth of mountains without a guide, especially as it snowed heavily now again. They found it very strange that Ladaki merchants took this road, and said it would be a wonder if we could keep clear of robbers; therefore, of course, the Mohammedans began to sing their hymns to Allah again.

We had passed Kinchen-la and camped in a valley going down to Raga-tasam on April 24, when we saw eight men leading their ponies 
and coming down from the pass. One could see by their dresses and arms that they were not ordinary nomads. Some of them went straight into Abdul Kerim's tent; their servants camped just outside the entrance of my tent where I kept hidden. They had a very lively palaver with Abdul Kerim ; and when they had gone to their camp, from which they kept their eyes upon my tent, I went the back way into my men's tent; and now Abdul Kerim told me they were sent from Saka-dsong, as the authorities there suspected amongst us was hidden Hedin Sahib from the last year. If they were mistaken they had orders anyhow to look through all our luggage; and then Abdul Kerim had only to write a statement that no European was hidden amongst us, and we could continue our journey.

At once I saw clearly the whole situation and the course to take. To write such a statement was a little too strong even for my elastic geographical morals, so I told my Ladakis I should tell the Tibetans the truth, happen what would afterwards. The honest men began to weep as children, believing that I should be killed on the spot at least. But I rose and went down to the Tibetans and sat down between them at their fire. I put my hand on the shoulder of my old friend, Pemba Tsering, from last year, and asked him if he did not recognize me at all. He only opened his eyes as wide as he could and looked round at his comrades without saying a word, but his looks meant as much asit is him. After a few minutes we were all friends, chattering and joking as if our meeting had been the most natural thing in the world. I had a delicious feeling of freedom now since $I$ was caught again by the Tibetans; I was no longer a prisoner in my own tent. I did not need any more to paint myself black as a Morian. I could wash-well, I won't tell what the water looked like after the first bath.

If I had not been discovered here I should have continued eastwards, and I had the little arrière pensée to come one day as a Ladaki beggar to Major O'Connor, and after some extraordinary conversation I should ask him for some more champagne and tell him who I was. But now we were caught, and now the principal thing for me was to play my cards well. I had crossed the province of Bongba only once, and now I wondered if I should be able to cross it on one or two other lines. Panchor was in our camp, and he told me such a lot of interesting things of Bongba, that if I had been perfectly free to go wherever I liked in Tibet, I should have gone to Bongba, and my dream was now to finish up definitely with the problem of Trans-Himalaya.

I cannot tell now all my extraordinary experiences during the following days, our meeting in Semoku with the authorities of Sakadsong, the distinguished Pun Dortche Tsuen, with attendants and escort, all in pomp and show, my real friendship with him, our picturesque journey back to Kamba Tsenam's tent, the kindness with which he let me take the very road I proposed-certainly not without 
risk for himself-no, I say, the eight days we were together would give material to a nice little book about the ways and views of the Tibetans. Well, I love them, I feel the deepest sympathy with them; they were always kind and polite and hospitable to me, and went as far as they possibly could without being disloyal to their own country, and after half a day's acquaintance we were as if we had known each other from childhood. 'The Lopliks used to call me Padishahim, or Your Majesty, and of course that title was more than enough for my ambition, but the Tibetans of Bongba called me always Rinpoche, or Your Holiness, the same title as is given to the Dalai Lama and Tashi Lama, and that I thought was a little too much for me. But it was well meant, and $I$ accepted the attention as a quite natural thing. In their company we went round the "High Nun," and at Kamba Tsenam's tent everything was arranged. I should have only five of my men with me, the rest under Abdul Kerim would go over Samje-la to Buptsang-tsangpo, where we had to meet. This was an excellent arrangement; it caused no end of confusion. The people of Bongba certainly believed Abdul Kerim's party was the head caravan, because Karma Puntso himself and six Govas caused them a lot of difficulties, and when I passed with only five men, and now in Tibetan dress, as all my European things were burnt long ago, and my Ladaki things worn out, nobody paid any attention to us. It even happened that nomads asked me when the "peling" should come, and I used to say he was behind, and if they kept their eyes opened they should see a most extraordinary fellow. So far as to Buptsang-tsangpo I should have an escort of ten soldiers, and they proved to be awfully fond of rupees.

The last evening we were together with the Saka authorities I invited them to a feast in my tent, in front of which a big fire burnt, and round it the Ladakis danced the dances of their country. I believe the Tibetans had never been so amused in their lives; they laughed, cheered, clapped their hands, and began to take part in the songs, and the whole time the snow came down as never before. It was late when the fire died away and my guests went to their own tents.

On May 6 we said good-bye to our new friends, and went straight north to the most important and interesting of all my Trans-Himalayan crossings. In the evening, in Gyegong-lungpa, a fellow came to my tent, telling me he had seen me seven years ago in Nakchu, and when I asked what his profession was, he answered-robber; but that is another story, as Kipling says. By the way, Kamba Tsenam told us that he was " the father of all Tibetan robbers," and a great friend with them. The next day we crossed by Gyegong-la the Kanchung-gangri range, which is not the head range, but broken through by the Chaktak-tsangpo. In Lapchung-tso, situated to the north of this range, all the rivulets meet, which, coming from the head range, form the upper Chaktaktsangpo. Here we passed a great trade road, being also a pilgrim's road, 
to Kang Rinpoche (Kailas). 'The country of Lapchung is very high and cold, and the winter remains here much longer than elsewhere in the Trans-Himalayan Alps. Several important rivers begin from this upheaval: the Keddo-tsangpo, Raga-tsangpo, and Chaktak-tsangpo to the south, Buptsang-tsangpo and Soma-tsangpo to the north.

On May 12 we went over Sangmo-bertik-la, surrounded by glaciers - the rock, as in all Trans-Himalayan passes I know, consisting of different varieties of granite. Wild yaks are numerous. Almost every day we had storm and snow. So we crossed the Soma-tsangpo, which is, I should say, the biggest of all rivers in the interior of Tibet. It comes from the western side of the Shuru-tso range and empties into Terinam-tso. May 19 we crossed Teta-la, from where one has the most brilliant view over the whole Teri-nam-tso, Trans-Himalaya, Targogangri, and Shakangsham. In this clear atmosphere one sees some 100 miles distant; everything is light blue, rose and white, and often the boundary between a high mountain range and heaven is only marked by the white dotted line of the eternal snows. Shakangsham is a kingly mountain, raising its shining white head like a lighthouse over the gigantic mountain waves of lonely and desolate Tibet. It dominates a wider area than any other gangri on the plateau-land, it tells you the road as the stars in the night, and at last it disappears under the horizon as a dream of snow and roses. And the lake is marvellous; one is charmed and fascinated by the intensity of its colour, at the side of which the heaven becomes pale and the torquoise loses its attraction. The lake has been almost correctly placed by Nain Singh, although he has never seen it, only heard of it. He writes the name Tede-nam-tso; it ought to be Teri-nam-tso, or the "Throne mountains heaven lake." In its eastern part there is a picturesque rocky island. The water is salt. Nain Singh's Ngangon-tso, nobody had ever heurd of here. Two days we followed the southern shore to the west end, and then went up to Mendong-gunpa on the Soma-tsangpo. The monastery has two Kanpo-lamas, one of whom is a rinpoche, sixty monks, and seventy nuns, all dwelling in very comfortable black tents. I suppose they have great fun together in the long winter evenings.

So we went up the Soma-tsangpo, crossed Goa-la, left the little Karong-tso to our left in Bongba-kemar, and fullowed one of the great "tsalams," or salt-roads, from Raga-tasam to Tabie-tsaka, left to our right Chunit-tso, which we knew before, and reached the Buptsangtsangpo in Bongba-kebyang, our meeting-point with the caravan which had disappeared altogether. On June 5 we said good-bye to the soldiers, and for three days we followed the Buptsang-tsangpo down to its mouth in Tarok-tso. Only two very poor peasants followed us, and I could have gone wherever I liked.

Tarok-tso has fresh water, but no visible outlet, showing that its water goes underground to Tabie-tsaka. It was my wish to visit this 


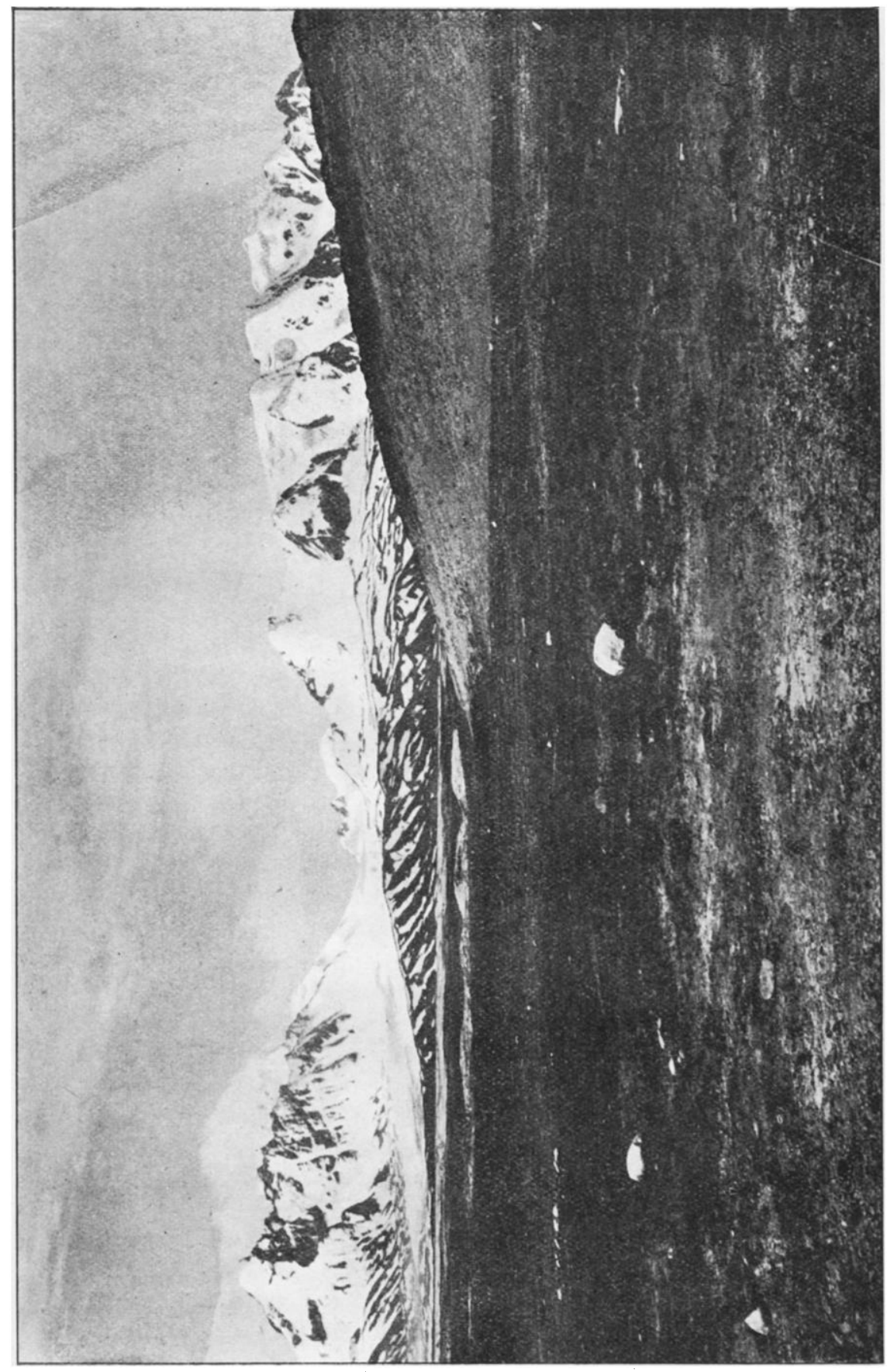

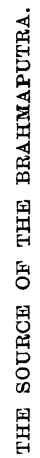

This content downloaded from 198.91.37.2 on Mon, 27 Jun 2016 03:22:10 UTC All use subject to http://about.jstor.org/terms 
important salt depression, where so many roads meet from all sides of southern Tibet, but the Gova of the place refused it, telling me to take the mountain road, which of course proved to be much more interesting, as I got the remaining unknown part of Trans-Himalaya very clear, and this would have been absolutely impossible if I had taken the Tabie road. And I could see Tabie-tsaka from a high mountain. The salt is said to be upon clay, and there is very little water. Natives of Bongba may break as much salt as they like; other caravans have to pay some tengas to Devashung for every hundred sheep-loads.

So we passed Lunkar-gunpa, which has twenty lamas, four nuns, and two rinpoches, being a daughter temple of Sera. Some days north, not far from Lakor-tso, there is Marmik-gunpa, with twenty-five monks and six nuns, and also affiliated to Sera. Lunkar-la is situated in the same range, which is called Hlunpo-gangri, north of Saka-dsong, but it is not a first-class watershed, as it divides the water only between 'larok-tso and Poru-tso ; to this lake Goang-tsangpo goes down. Poru-tso is salt, and its old beachlines, which I measured, are 108 metres (354 feet) above the present surface of the lake, showing an enormous desiccation. At Lakor-tso I had measured old shorelines 133 metres (436 feet) high. Then we crossed Nyapchu-tsangpo coming from Men-la in TransHimalaya and going to Poru-tso; west of this lake we went over the beautiful ice- and snow-covered Surla range-I call it so from Sur-la, a rather high and difficult pass. On the western side is Rigi-changma, or Rundor; and here we followed north the big river of Pedang-tsangpo down to Shovo-tso, which also is salt. Our guides were two boys, one of them ten years old. I really do not know what the Tibetans were thinking of, leaving us quite alone.

From Tajep-parva-la one sees almost the whole Nganglaring-tsocalled Ghalaring-tso on our maps. I suppose some pundit has discovered the lake, although I am not sure if he has ever been there, because the map is very wrong. He says, "Monastery on island," and has one little island in the lake; there are five islands, but not a single monastery; and he makes the lake extend from north to south instead of east to west. We followed this big salt lake for two days west; from the south Sumdang-tsangpo comes out. From south-west comes Lavar-tsangpo, which joins with the Aong-tsangpo from west-south-west, a river which begins from the eastern side of the mountains which to the west give rise to the Indus.

On June 26 I camped at Selipuk, and was received with the greatest hospitality by the lamas of this temple. One of them I had met in Raga-tasam, another in Lelung-gunpa last year, and the Pun, Sonam Ngurbu, of Chokchu, was just here on his prilgrimage to Kang Rinpoche. Him I knew at Shigatse, and he was very polite, as be had seen how well the Tashi Lama had received me. It was interesting to see the Pun's caravan; he had a real village of tents, travelled with all No. IV.-APRIL, 1909.] 
his household, a hundred persons, had four hundred yaks and four hundred sheep, and a great and picturesque escort of armed men. He has two younger brothers, and all three have two wives together, that means two-thirds of a wife each, which $I$ think is a rather funny invention. I was very short of money, so his presents of tsamba and rice and sugar were very welcome; all our silver was with the head caravan, and when those fellows found us two days later I had exactly one tenga (= six annas) left, and was about to sell ponies, revolvers and watches as a wandering Jew.

From Selipuk we went south-west to Tokchen. As this line is parallel with my journey to Yumba-matsen the previous year, it is of great interest. Here we cross the Trans-Himalaya by the two passes Ding-la and Surnge-la, Ding-la being very high, Surnge-la easy, although it is the head pass, the watershed between Lavar-tsangpo going to Nganglaring-tso and the Sutlej. North of Surnge-la is Argok-tso, from which a tributary goes to Aong tsangpo. Everywhere it would have been very easy to slip away to the north or east or anywhere, as nobody looked after us, but by that time I had got about enough of Tibet after those two long years.

Now only a few words as a résumé or conclusion about TransHimalaya. The map shows that those two years of wanderings circulate around and across Trans-Himalaya, and that this mountain system has been the chief object of my attention, and I believe I will call my next book, the dedication of which H.E. the Viceroy has kindly accepted, 'Trans-Himalaya.' Because, even if certain parts of it were known before, Trans-Himalaya as a whole geographical unit is a new conquest on our Earth, a new geographical region and signification, that has been more neglected than even the moon, and now it will be introduced for evermore into geographical literature, and the poor schoolboys of future generations will get a new name to remember.

Himalaya has always been regarded as the strongest possible fortress for India against eventual dangers from the north; let us not forget that this fortress-wall, this natural defence of solid granite, is double, and it would be rather amusing to see a northern enemy try and jump over those two walls with the Indus-Brahmaputra grave between them. The Capuchin Father Georgi tells us in his admirable book, ' $\mathrm{Al}_{4}$,habetum Tibetanum,' how the great Dsungar Khan Tsagan Araptan in 1717 sent an army under Seren Donduk from Khotan through the whole of Tibet to Lhasa, and how this army, although frightfully diminished and several times beaten by the Tibetans, could conquer Lhasa in the time of Ngavang Yishe Jamtso Dalai Lama. And we know from Turner, and lately from Sir Thomas Holdich's fascinating description, how Emperor Kiang Lung in 1792 sent an army of 70,000 men from Mongolia, Sechuan, and Yunnan, to Tibet, and how this 


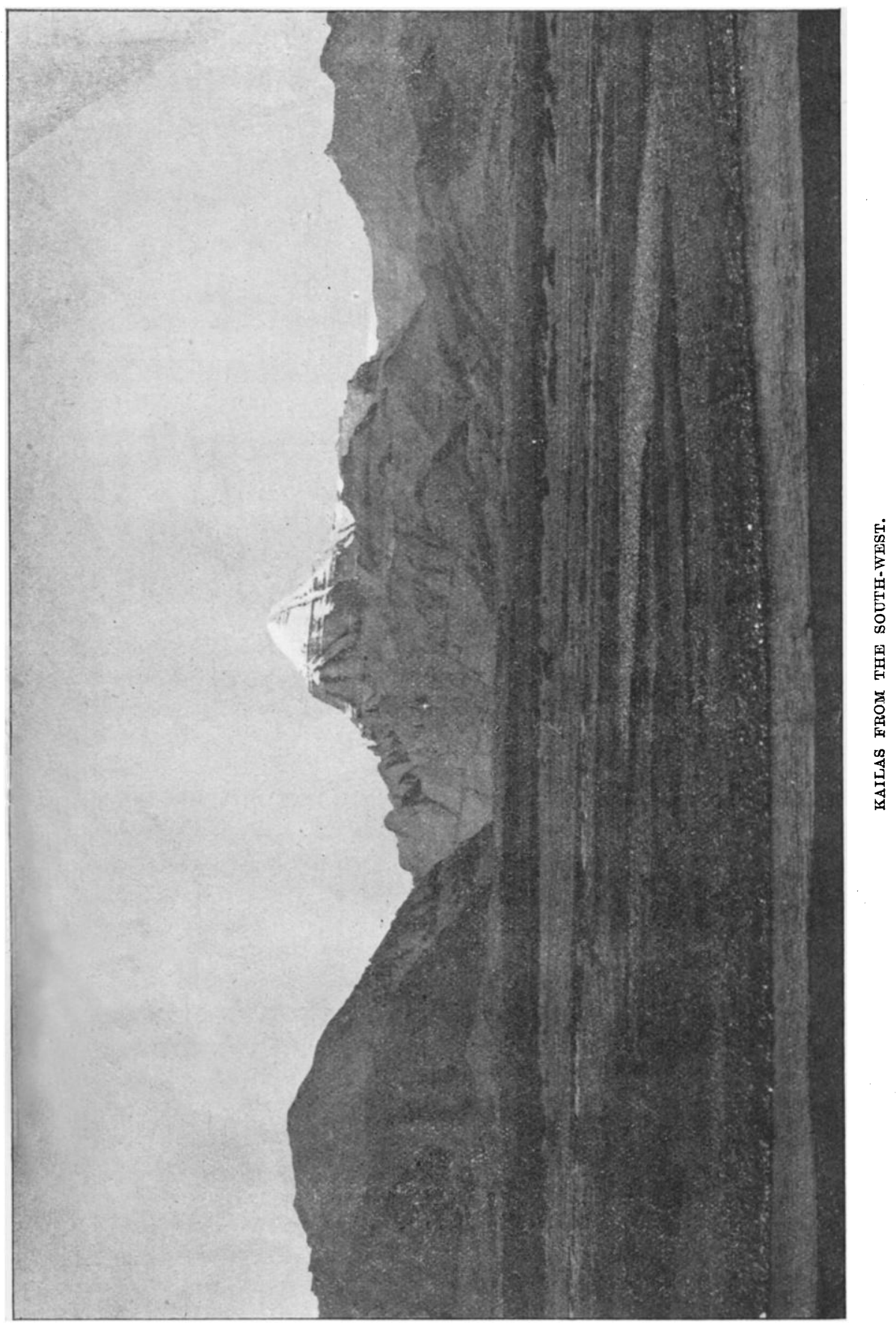

2 D 2

This content downloaded from 198.91.37.2 on Mon, 27 Jun 2016 03:22:10 UTC All use subject to http://about.jstor.org/terms 
army beat the Gurkhas from Nepal both at Tingri and Kuti since the Gurkhas had plundered Tashi-lunpo twice. But those performances of very irregular troops can hardly be compared with modern warfare. Even light field artillery could only with the greatest difficulty be transported over Tibet, and a strategical railway would be an absurdity. In the great latitudinal valleys there is no hindrance to a railway, but I cannot see how the material could be brought there, and thenthose valleys do not lead to India. I have tried with camels, highland ponies, Tibetan mules, yaks and sheep, but as a rule one crossing takes ninety or ninety-three per cent. of the caravan. Often one camps at a spring where the grass is just sufficient for one's animals, but how should it be sufficient for an army. As a rule even a little but strong caravan is spoilt and ruined before it reaches those parts of Central Tibet where grass is abundant, and then it is of no use to try with ponies and mules from the lowlands. My experience has always been that ponies from Eastern Turkestan are the first to die, whereas the Sanskar ponies are the best. I think it is difficult to find another country that has got-from a strategical and defensive point of viewsuch a favourable geographical situation as India, and all those fears expressed by Vambery or General McGregor are, to use rather a polite word, much exaggerated.

As to the name Trans-Himalaya, I should not have introduced it into geographical literature unless it had had tradition for itself, and the Viceroy of India had given his approval to it, and I am glad to say His Excellency has found it good. As I have said, I was about to call the system, Nien-chen-tang-la, or Hlunpo-gangri, but by that time I had no clear conception of the enormous dimensions of these mountains. Such names are not sufficient. Then I was thinking of "the South Tibetan Mountain system," but that is an ugly and uncomfortable name, whereas Transhimalaya tells us at once that this mountain system is situated on the other side of the Himalayas, and is thus a real scientific and characteristic name that cannot possibly give rise to any kind of confusion or misunderstanding. And we have not to go far into Asia to find cases of precedence. Sakaspijskij Oblast, or Transcapsia, is the great province on the other side of the Caspian Sea. Transcaucasia, Transoxiana, and Transbaikalia are all names that do not need any further explanation. The Transilenian Ala-tau is the range situated on the other side of Ili. But the most beautiful case of precedence is found in Fergana, south of which province is the Alai Range. South of Alai is the great broad valley of Kisil-su, being a right tributary to Panj or Amu-darya, and south of this valley is a range called Transalai, because it is situated on the other side of the Alai range. South of Transalai is the plateauland of the Pamirs. Now everybody will see how very like this orographical arrangement is to our present case, the plains of Fergana corresponding to the plains of Northern India, Alai to 
Himalaya, Kisil-su to the Indus-Brahmaputra valley, Transalai to Trans-Himalaya, and the plateauland of the Pamirs, the Roof of the World, to the plateauland of Tibet.

Trans-Himalaya is one of the greatest mountain systems on the earth regarding its length, breadth and height, and it can only be compared with the Himalayas, Kwen-lun, Arka-tagh, Karakorum, Tien-Shan, the Cordilleras de los Andes, the Rocky Mountains. From Nub-kong-la to Ladak it is 1100 miles long, but east of Nub-kong-la it continues no doubt some hundred miles south-east and west of Ladak; if it can be proved that it is in connection with the Hindu-kush, its length should be some 2000 miles.

Nowhere is it a single range, it is at least two, but as a rule three or four. In the south its frontier is clearly given by the IndusBrahmaputra valley; in the north I should say the belt of central lakes, the eastern discovered by Nain Singh, the western by me, is a quite natural and practical boundary, as the ranges situated to the north of those lakes, although some of them may be interwoven with the northern ramifications of the Trans-Himalayan ranges, ought to be called, "The Central Tibetan Alps." They are much lower than the Trans-Himalaya. On both sides of them there is comparatively low land, two latitudinal depressions corresponding to the great latitudinal valleys of Chang-tang. In the northern depression we have the Sachutsangpo, Selling-tso, Chargu-tso, Addan-tso, Bogtang-tsangpo, Tong-tso, Lakor-tso, Luma-ring-tso, etc.; in the southern: Kyaring-tso, Tsikutso, Ngangtse-tso; Dangra-yum-tso, Teri-nam-tso, Tabie-tsaka and Nganglaring-tso, whereas Nam-tso, Shuru-tso, Karong-tso, Chunit-tso, 'Iarok-tso, Poru-tso, Shovo-tso, Argok-tso, and Panggong-tso more intimately belong to the Trans-Himalayas. Amchok-tso, Lapchung-tso, and Senit-tso are situated south of the head watershed.

The breadth of the Trans-Himalayan system, where it is broadest, is some 120 miles, whereas the broadest part of the Himalayas is about 200 miles. The average breadth of our system may be said to be 80 to 100 miles; it is broadest in the middle, in Bongba, and becomes narrower to the east and west, at Panggong-tso, for instance, its breadth being only some 30 miles.

I have mentioned the principal eastern passes, and will now add some more to the west. Between my two passes, Angden-la and Sangmo-bertik-la, are Tsalam-nakta-la, Dombe-la, and Nakbo-kongdo-la, the first of which is important, as a great salt road crosses it. Between Sangmo-bertik-la and Samje-la are Saggo-la and Dicha-la, both of which I could see from my road. Then comes the great gap between Samje-la and Surnge-la, where I have not made any crossings, and where the following passes are situated: Dsalung-la, Lungmar-la, Pechen-la, Lungnak-la, Jor-la, Ganglung-la, Men-la, Pedang-la, Gebbji-la, and Tarkyang-la. West of Surnge-la is my Lachen-la. There are said to 
be some other passes used only by hunters, shepherds, and robbers, but not for trade, travelling, or pilgrimage. West of Yukti-la, which, I believe, has been crossed by Mr. Calvert some four years ago, there are several passes, most of them easy, but some snowed over and closed in winter.

The orographical and hydrographical rank of the Trans-Himalayas is more distinguished and important than that of the Himalayas. The western Himalayas are a watershed between the Indus and its tributaries, the eastern part between the Brahmaputra and the Ganges; but every drop of water that falls in the Himalayas goes to the ocean. On the other hand, almost the whole central part of the Trans-Himalayas is a watershed between the Indian ocean to the south and the selfcontained plateau depressions to the north, from where the water never reaches the ocean. In the far west the Trans-Himalaya is also a watershed between the Indus and some of its higher tributaries, and in the far east it is a watershed between the Brahmaputra and the Salwen. Except the Salwen, there is, within Tibet, only one river that, beginning from the northern side of the Trans-Himalaya, reaches the ocean; but this river is a lion, and the Tibetans call it also Singetsangpo, the Indus, which breaks through the range in a transverse valley. Other rivers from the northern side of the Trans-Himalaya are doomed to die, or rather, evaporate in salt lakes without outlet. From east to west the principal of them are: Ngang-chu, Ti-chu, and Bo-chu to Nam-tso, Ota-tsangpo, and Bara-tsangpo falling into Kyaring-tso, which is a fresh-water lake; Tagrak-tsangpo to Ngangtse-tso; Targo-tsangpo to Dangra-yum-tso; Soma-tsangpo to Teri-nam-tso; Buptsang-tsangpo to Tarok-tso, which is fresh; Goang-tsangpo and Nyapchu-tsangpo to Poru-tso; Pedang-tsangpo to Shovo-tso; Sumdang-tsangpo, Lavartsangpo, and Aong-tsangpo to Nganglaring-tso. The great geographical homology of this arrangement is very curious and interesting.

The principal Trans-Himalayan ranges are, Nien-chen-tang-la, which further west is called Kanchung-gangri, and dies away to the north-west, north of Samje-la, then the Targo-gangri-Shuru-tsoLapchung range, finishing at Tarok-tso, and north of it is the Teri-namtso range. Further west we have the Hlumpo-gangri-Lunkar range, one of the very highest, and then the Surla range between Poru-tso and Shovo-tso. South of Selipuk is the Ding-la range and the Surnge range, which is the same as the one north of Kailas, and which further west is broken through by the Indus.

Transhimalaya is situated in or touches the following provinces: Kham, Nakchu, U, Tsang, Naktsang, Saka, Chokchu, Bongba, RundorSelipuk, Singtod-singmet, Ngari-khorsum, and Rudok; that is to say, most of inhabited Tibet.

The province of Bongba, and that of Chokchu, were the only ones in Tibet which hitherto have remained absolutely unknown to 
Europeans-I believe even their names were unknown. Bongba is divided into twelve districts, with a Gova as chief of every one of them. It is a well-populated country, with a great many tents, sheep, and yaks; thus the district of Bongba-changma was said to have 300 tents. During such a year as this, when the grass is bad, as there was no rain in 1907 , a great part of the nomads go north to the central plateauland where the grass is better.

The province is crossed by innumerable roads. I distinguished seven different sorts of roads-gold roads, salt roads, trade roads, administrative roads, pilgrims' roads, nomads' roads, and robbers' roads. The last category are practically no roads, as they go where nobody else is going. The Serpun-lam, or " the gold-inspectors' road," also called Ser-lam, or "the gold road," is one of the most important roads in all Tibet. It begins from Lhasa, crosses Guring-la, passes Shansa-dsong, goes south of Dangra-yum-tso, north of Teri-nam-tso and Tabie-tsaka, crosses the Surla range in Ka-la, and continues to Selipuk, Yumba-matsen, and Tok-jalung. The salt roads, or "Tsalam," converge from all parts of Tibet to Tabie-tsaka, and many of the Trans-Himalayan passes I have mentioned are taken by the salt caravans. By administrative roads I mean simply local tracks used by representatives of certain districts, who, on a certain day every year, come to a certain place where the Government officials meet to collect the contribution they have to pay for the right of using the grazing-grounds to their flocks.

But now I must finish, and I hope you will excuse the length of this paper. I wrote it between Selipuk and Tokchen, and it is fortythree pages long in manuscript. So, as my diary is a little more than 6200 pages long, I should have to deliver one hundred and forty lectures like this if I should be able to give all the information I have brought home. This lecture is thus a very short account of a very long journey, the results of which it will take two or three years to work out. But, once put into order and published, I hope it will prove to be of some use to India, and then my work in the grand loneliness of Tibet will not have been in vain.

The President (before the lecture): We welcome here to-night the man who, without doubt, has done more than any single individual has ever done to add to the knowledge possessed by the civilized world of Central Asia. It is useless to attempt to condense into a few short sentences all that Dr. Sven Hedin has done for geographical science, and I shall limit myself to reminding you very briefly of the occasions of his two last visits to London. The first of these two visits was in 1898, shortly after he had concluded his great four years' journey in Central Asia, a journey in which, in the opinion of your President, Sir Clements Markham, he encountered "desperate dangers and hardships," and did work which in the circumstances was notable for completeness and thoroughness. Not long after Dr. Sven Hedin had described to us his experiences on that journey, he was awarded 
Kratidinger

- Mrarghi 20573

in Futalitik nos

Daknalpo

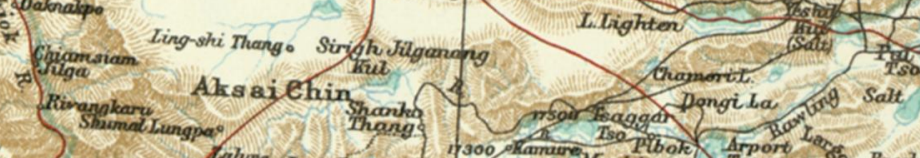

Ling-sh Thang
iehingh Singeng (White Desert) 236

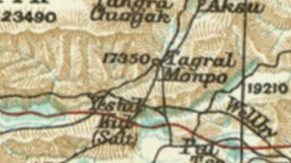



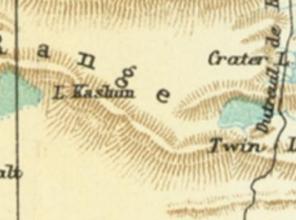
की
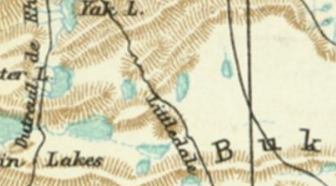


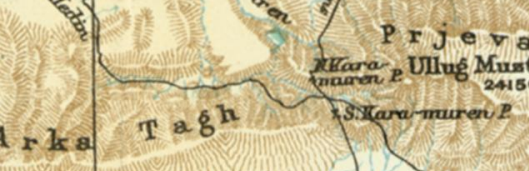
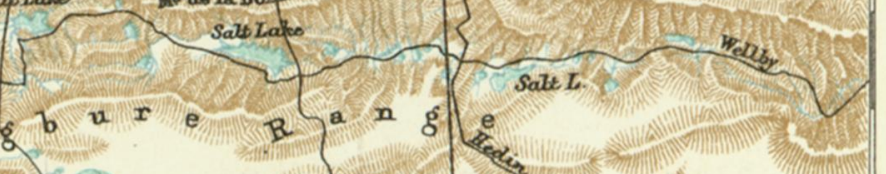

a

R.

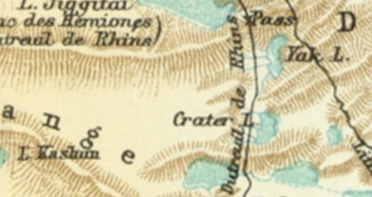

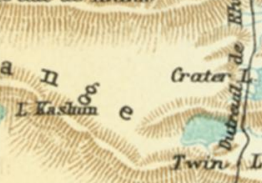
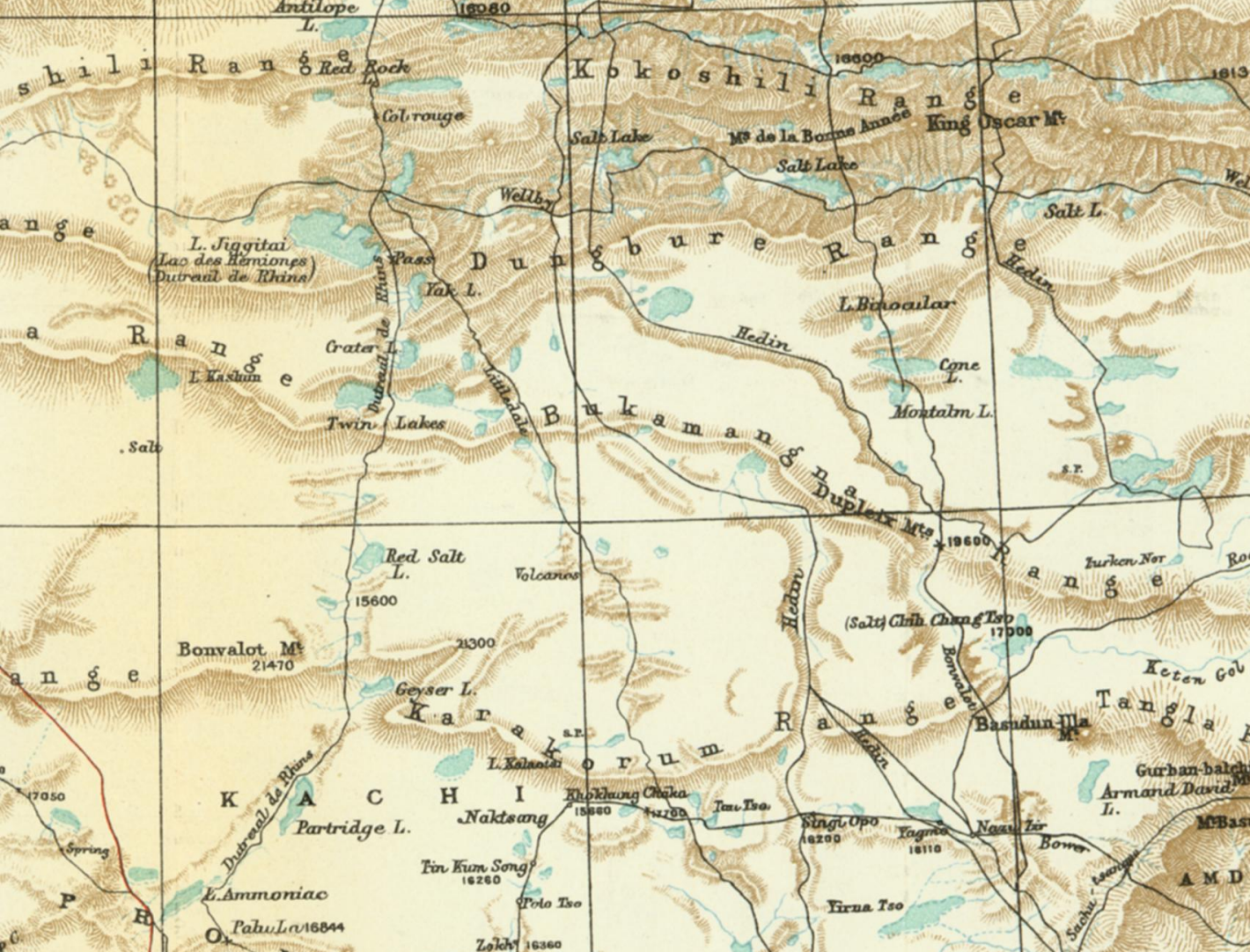
